\title{
First-time Blood Donors Are Double-edged Swords for Blood Transfusion Centers: A Retrospective Study in Southwest Iran
}

\author{
Illk Kez Kan Vericisi Olanlar Kan Transfüzyon Merkezleri için Iki Ucu Keskin Bıçaktır: \\ Güneybatı Iran'dan Retrospektif Bir Çalışma
}

\author{
(D) Hamid Reza Niazkar¹, (D) Akbar Dorgalaleh², (D) Fariba Rad33,4 \\ ${ }^{1}$ Gonabad University of Medical Sciences, Student Research Committee, Gonabad, Iran \\ 2School of Allied Medical Science, Department of Hematology and Blood Transfusion, Tehran, Iran \\ 3 Yasuj University of Medical Sciences, Cellular and Molecular Research Center, Yasuj, Iran \\ ${ }^{4}$ Blood Transfusion Research Center, High Institute for Research and Education in Transfusion Medicine, Tehran, Iran
}

\section{Abstract}

Objective: First-time blood donors are the most common group of blood donors. They usually have different motivations for blood donation, some of which provoke the donors to hide risk factors of transfusion-transmissible infections (TIs). Therefore, detection of TTls among first-time donors is crucial and can decrease the rate of TTls among blood recipients. This study aimed to evaluate the prevalence of TTls among first-time donors in the transfusion center of Kohgiluyeh and Boyer-Ahmad Province (KBTC), Iran.

Materials and Methods: This retrospective study was conducted with volunteer blood donors in 2004-2014 in the KBTC. Various data, including sex, confidential unit exclusion (CUE), previous donation history, and the laboratory findings of confirmatory tests, were extracted from blood donor software. Data were analyzed by SPSS using the chi-square test.

Results: Among 198,501 blood donors, 52,527 (26.46\%) were firsttime donors, while 145,974 donors (73.54\%) were repeat and regular donors. Most of the donors (94.5\%) were male, while a minority (5.5\%) were female. The CUE option was chosen by 2,237 (1.13\%) donors. The incidence of hepatitis B surface antigen ( $\mathrm{HBsAg})$ and hepatitis $\mathrm{C}$ virus (HCV) was $247(0.13 \%)$ and $134(0.07 \%)$ among the entire study population, respectively. Three donors $(0.002 \%)$ had confirmed human immunodeficiency virus (HIV), while none of the blood donors were positive for syphilis. Most of the donors with positive HBsAg (95.8\%), HCV (86.6\%), and HIV (100\%) infection were first-time donors.

Conclusion: Since Tाls are more common among first-time blood donors than regular and repeat donors, special considerations should be taken into account for this common group of blood donors.

Keywords: Transfusion-transmissible infections, Blood donor, Blood donation

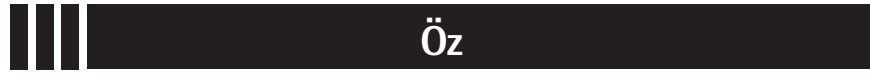

Amaç: Kan donörlerinin büyük çoğunluğunu ilk kez kan veren donörler oluşturmaktadır. Bu kişilerin genellikle kan vermek için farklı motivasyonları vardır ve bu da vericilerin transfüzyon ilişkili enfeksiyonları (TI) saklaması açısından risk oluşturur. Bu nedenle ilk kez verici olanlarda TI'ları tespit etmek çok önemlidir ve böylece kan alıcılarında TTI'lar azaltılabilir. Bu çalışmada amaç İran'da Kohgiluyeh ve Boyer-Ahmad Bölgesi (KBTC) transfüzyon merkezindeki ilk kez verici olan kan donörlerinde $\Pi$ I prevelansının araştırılmasıdır.

Gereç ve Yöntemler: Bu çalışma, KBTC'de 2004-2014 yılları arasında gönüllü kan vericilerinin dahil edildiği retrospektif bir çalışmadır. Cinsiyet, gizli ünite dışlaması (CUE), daha önceki kan bağışları, ve doğrulama testlerinin laboratuvar bulguları gibi veriler, kan vericileri yazılımından elde edilmiştir. Elde edilen veriler ki-kare testi kullanılarak SPSS ile değerlendirilmiştir.

Bulgular: 198,501 kan vericisinden 52,527'i $(\% 26,46)$ ilk kez kan veren donörler, 145,974 'i ise düzenli olarak kan verenler veya daha önce kan vermis olanlardı $(\% 73,54)$. Vericilerin çoğu erkekti $(\% 94,5)$, kadın verciler azınlıktaydı $(5,5 \%)$. CUE seçeneği 2,237 (\%1,13) verici tarafından kullanılmıştı. Bütün çalışma grubunda hepatit $B$ yüzey antijeni (HBsAg) ve hepatit C virüsü $(H C V)$ sıkığı sırasıyla $247(\% 0,13)$ ve $134(\% 0,07)$ idi. Üç vericide doğrulanmış insan bağışıklık yetmezliği virüsü (HIV) bulundu $(\% 0,002)$, hiç bir hastada sifilis tespit edilmedi. HBsAg (\%95,8), HCV (86,6\%), ve HIV (100\%) enfeksiyonu olan vericilerin çoğunluğu ilk kez kan vericisi olan gruptaydı.

Sonuç: TI'lar tekrarlayan kez verici olanlar veya düzenli verici olanlarla karşılaştırıldığında ilk kez verici olanlarda daha sık görülmektedir ve bu vericilerin kullanılması durumunda özel önlemlerin alınması gereklidir.

Anahtar Sözcükler: Transfüzyon ilişkili enfeksiyonlar, Kan vericisi, Kan bağışı

•Copyright 2020 by Turkish Society of Hematology

Turkish Journal of Hematology, Published by Galenos Publishing House

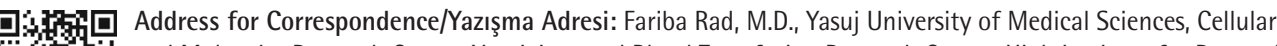
and Molecular Research Center, Yasuj, Iran and Blood Transfusion Research Center, High Institute for Research and Education in Transfusion Medicine, Tehran, Iran

Phone : +98 9196028093

E-mail : fariba.rad89@gmail.com ORCID: orcid.org/0000-0002-6143-9979

Received/Geliş tarihi: April 26, 2019 Accepted/Kabul tarihi: September 2, 2019 


\section{Introduction}

Blood transfusion has a fundamental role in medical services. Although blood donation can improve the quality of patients' lives, it is one of the main causes of the transmission of viral infections, including hepatitis B virus (HBV), hepatitis C virus (HCV), and human immunodeficiency virus (HIV). Several studies have shown that the chance of transmission of these infections is about $1 \%$ in each blood unit transfusion, while a $6.2 \%$ chance to transmit hepatitis was also reported $[1,2,3,4]$.

Since blood can only be provided by human resources, transfusion-transmissible infections (TIs) via these products are important issues. Therefore, blood safety is the most important concern of blood transfusion worldwide [5]. In the process of ensuring blood safety, donors have a crucial role [6]. As a result, standard and relatively strict blood donation conditions are used by blood transfusion centers to improve blood safety. This includes a voluntary blood donation system, a confidential unit exclusion (CUE) system, the exclusion of high-risk donors, and standard and sensitive blood-borne disease detection systems. High-risk donors are those with risky behaviors, such as multiple sexual partners or intravenous drug injection, which can increase the risk of TTls $[7,8,9]$.

According to the standards of blood transfusion organization, volunteer donors are classified into two groups: first-time donors and repeated and regular donors [10]. Several studies have shown that first-time blood donors are the most common group of blood donors [10]. These donors usually have different motivations for blood donation. Some of these motivations provoke donors not only to hide risk factors during interviews but also to increase the risks of the blood donation system. At the same time, studies in different communities have shown that the prevalence of TTls in first-time donors is higher than that of other donors [10]. Therefore, evaluation and detection of TTls in first-time donors are crucial and can decrease the rate of TTls among blood recipients.

Despite various strategies and significant advances in the detection and diagnosis of these diseases and the reduction of the window period by new-generation diagnostic kits, TIs remain the most important challenge in blood transfusion. This study aimed to evaluate the prevalence of TIs among first-time donors at the transfusion center of Kohgiluyeh and BoyerAhmad Province, Iran (KBTC).

\section{Materials and Methods}

This retrospective study was performed with 198,501 volunteer blood donors from 2004 to 2014 at the KBTC. Demographic data including sex and CUE, as well as donation history and laboratory findings of confirmatory tests, were extracted from blood donation software. Blood donors were classified into two groups as first-time donors or repeated and regular donors. A first-time donor is a donor who is donating blood for the first time. A repeated and regular donor is a donor who has donated blood at least once in the past [10].

The results of HIV, HBV, HCV, and syphilis tests were also extracted. The screening tests were performed with commercially available enzyme-linked immunosorbent assay kits.

Hepatitis B surface antigen (HBsAg) was checked with Behring (Marburg, Germany), Siemens (Marburg, Germany), and Bio-Rad (Hercules, CA, USA) kits; anti-HCV was checked with BioMerieux (Marcy l'Etoile, France) and Avicenna (Avicenna Medical Center, Moscow, Russia) kits; and HIV-Ab was tested with BioMerieux (Marcy I'Etoile, France), Bio-Rad (Hercules, CA, USA), and Adaltis (Montreal, Canada) kits. All repeatedly reactive results were confirmed by a neutralization test (Behring, Marburg, Germany) for HBV, a recombinant immunoblot assay for HCV (Inonogenetic, Ghent, Belgium), or a western blot assay for HIV (Inonogenetic, Ghent, Belgium).

According to Iranian Blood Transfusion Organization (IBTO) policies, each blood unit with positive results confirmed for blood-borne diseases was excluded and the corresponding donor was recalled for counseling and appropriate treatment.

The rate of confirmed positive HBV, HCV, and HIV tests was compared between the studied groups. The frequencies of $\mathrm{HBsAg}, \mathrm{HIV}$, and HCV and 95\% confidence intervals (Cls) were calculated using SPSS software. The prevalence rate of infections was calculated for each group and compared using the chi-square test, and differences were considered significant at $p<0.05$. This study was approved by the ethic committee of Yasuj University of Medical Sciences (IR.Yuma.rec.1396.22).

\section{Results}

A total of 198,501 blood donations were performed from 2004 to 2014 at the KBTC. These included 52,527 (26.46\%) first-time donors and 145,974 (73.5\%) repeated and regular donors. Out of the total of 198,501, 187,691 donors (94.5\%) were male and 10,810 donors (5.5\%) were female (17.1:1). The CUE option was chosen by 2,237 (1.13\%) donors, while 196,264 (98.87\%) of the volunteer donors did not choose the CUE option and were thus considered as the CUE-negative group. According to the history of donation, the distribution of blood donors in CUE groups is presented in Table 1.

Among the 198,501 blood donors, 247 (0.13\%) and 134 (0.07\%) donors were positive for $\mathrm{HBsAg}$ and $\mathrm{HCV}$, respectively. $\mathrm{HBsAg}$ had higher prevalence compared to $\mathrm{HCV}$ infection in the entire study population $[0.13 \%$ and $0.07 \%$, respectively; odds ratio $(\mathrm{OR})=1.84 ; 95 \% \mathrm{Cl}=1.49-2.27 ; \mathrm{p}<0.0001]$. Three donors 
(0.002\%) had confirmed HIV and none of the blood donors were positive for syphilis. In addition, concomitant infections were not detected in any donor.

Among the 52,527 first-time blood donors, 231 (0.44\%), 116 (0.2\%), and $3(0.005 \%)$ donors were positive for $\mathrm{HBsAg}, \mathrm{HCV}$, and HIV, respectively. HBsAg had a higher prevalence than HCV infection among first-time donors $(\mathrm{OR}=1.98 ; 95 \% \mathrm{Cl}=1.59$ 2.48; $p<0.0001)$.

In the population studied in this investigation, $1.08 \%(24 / 2,237)$ of CUE-positive and $0.18 \%(357 / 196,264)$ of CUE-negative donors were positive for disease markers. Table 2 shows a significantly higher prevalence of $\mathrm{HBsAg}$ and $\mathrm{HCV}$ in the CUE-positive than CUE-negative donors (1.08\% and $0.18 \%$, respectively; $\mathrm{OR}=5.84 ; 95 \% \mathrm{Cl}=3.875-8.820 ; \mathrm{p}<0.0001)$.

The prevalence of confirmed HBsAg was 1.32\% $(14 / 1,060)$ and $0.42 \%(217 / 51,467)$ among the first-time CUE-positive and first-time CUE-negative donors, respectively $(\mathrm{OR}=3.1$; $95 \% \mathrm{Cl}=1.814-5.312 ; p<0.001)$. The prevalence of confirmed HCV was $0.85 \%(9 / 1,060)$ and $0.21 \%(107 / 51,467)$ among the first-time CUE-positive and first-time CUE-negative donors, respectively $(\mathrm{OR}=4.05 ; 95 \% \mathrm{Cl}=2.060-7.990 ; \mathrm{p}<0.0001)$ (Table 3). There were 3 HIV-positive donors among the CUE-negative first-time donors.
A significantly higher prevalence of HBsAg and HCV infection was observed in male donors than females among the first-time donors $(p<0.001)$ (Table 4).

\section{Discussion}

Blood and its components are among the most important causes of $\mathrm{TI}$ transmission. The possibility of $\mathrm{TI}$ transmission in the transfusion of every blood unit is about 1\% [6]. This is a relatively high rate for transmission of blood-borne diseases because some of these infections are severe, life-endangering ones that are incurable or have a difficult treatment process $[6,7]$. Thus, TTIs are a significant challenge for blood transfusion services worldwide and require precise precautions. Different factors such as vaccination programs, high-risk behaviors, and the socioeconomic status of people can affect the risk of TTIs in any community. In recent decades vaccination against HBV significantly decreased the rate of TIs in different countries. In Iran, vaccination against HBV significantly decreased the rate of HBV infections in comparison with countries without this program or those with late establishment. The incidence of $\mathrm{HBV}, \mathrm{HCV}$, and HIV is also higher in low-income countries than in middle- and high-income countries. These data show that there is a direct correlation between the economic condition of countries and TI incidence. Those countries with higher income

Table 1. Distribution of blood donors in confidential unit exclusion -positive and confidential unit exclusion-negative groups.

\begin{tabular}{|c|c|c|c|c|c|}
\hline Group & $\begin{array}{l}\text { Total donations, } \\
\text { n (\%) }\end{array}$ & $\begin{array}{l}\text { First-time, } \\
\text { n (\%) }\end{array}$ & p & $\begin{array}{l}\text { Repeated and regular, } \\
\text { n }(\%)\end{array}$ & p \\
\hline CUE-positive & 2,237 (1.13) & 1,060 (2.01) & \multirow[b]{2}{*}{$<0.001$} & 1,177 (0.81) & \multirow[b]{2}{*}{$<0.001$} \\
\hline Total & $198,501(100)$ & $52,527(100)$ & & $145,974(100)$ & \\
\hline
\end{tabular}

Table 2. The prevalence of confirmed hepatitis B surface antigen and hepatitis $C$ virus among confidential unit exclusion-positive and confidential unit exclusion-negative groups.

\begin{tabular}{|c|c|c|c|c|c|c|c|}
\hline Group & $\begin{array}{l}\text { Study population, } \\
\text { n ( } \%)\end{array}$ & $\begin{array}{l}\text { HBsAg, } \\
\text { n (\%) }\end{array}$ & p & $\begin{array}{l}\text { HCV, } \\
\text { n (\%) }\end{array}$ & $\mathbf{p}$ & $\begin{array}{l}\text { Total, } \\
\text { n (\%) }\end{array}$ & $\mathbf{p}$ \\
\hline CUE-positive & $2,237(1.13)$ & $14(0.63)$ & \multirow[t]{2}{*}{$<0.0001$} & $10(0.45)$ & \multirow[t]{2}{*}{$<0.0001$} & $24(1.08)$ & \multirow[t]{2}{*}{$<0.0001$} \\
\hline Total & $198,501(100)$ & $247(0.13)$ & & $134(0.07)$ & & $381(0.2)$ & \\
\hline
\end{tabular}

Table 3. Comparison of hepatitis B surface antigen and hepatitis C virus prevalence among the confidential unit exclusionpositive and confidential unit exclusion-negative first-time donors.

\begin{tabular}{|l|l|l|l|l|}
\hline \multirow{2}{*}{ HII } & Group of donations & Number of donations & Number positive, n (\%) & $\mathbf{p}$ \\
\cline { 2 - 5 } & First-time, CUE-positive & 1,060 & $14(1.32)$ & $<0.0001$ \\
\cline { 2 - 5 } & First-time, CUE-negative & 51,467 & $217(0.42)$ & $8(0.85)$ \\
\hline \multirow{2}{*}{ HCV } & First-time, CUE group & 1,060 & $107(0.21)$ & $<0.0001$ \\
\cline { 2 - 5 } & First-time, non-CUE group & 51,467 & & \\
\hline
\end{tabular}




\begin{tabular}{|c|c|c|c|c|c|c|c|c|c|c|c|}
\hline \multirow[t]{3}{*}{ Year } & \multirow{3}{*}{$\begin{array}{l}\text { Total } \\
\text { donations }\end{array}$} & \multicolumn{10}{|c|}{ First time donors } \\
\hline & & \multirow{2}{*}{$\begin{array}{l}\text { Total } \\
\text { HbsAg- } \\
\text { positive }\end{array}$} & \multicolumn{2}{|l|}{ Sex } & \multirow{2}{*}{$\begin{array}{l}\text { OR } \\
(95 \% \mathrm{CI})\end{array}$} & \multirow{2}{*}{$\begin{array}{l}\text { Significance } \\
\text { level }\end{array}$} & \multirow{2}{*}{$\begin{array}{l}\text { Total } \\
\text { HCV- } \\
\text { positive }\end{array}$} & \multicolumn{2}{|l|}{ Sex } & \multirow{2}{*}{$\begin{array}{l}\text { OR } \\
(95 \% \mathrm{Cl})\end{array}$} & \multirow{2}{*}{$\begin{array}{l}\text { Significance } \\
\text { level }\end{array}$} \\
\hline & & & Male & Female & & & & Male & Female & & \\
\hline 2004 & 13,063 & 33 & 25 & 8 & $\begin{array}{l}2.2 \\
(1.114 .4)\end{array}$ & 0.02 & 8 & 7 & 1 & $\begin{array}{l}4.2 \\
(0.61-28.8)\end{array}$ & 0.1 \\
\hline 2005 & 13,270 & 18 & 14 & 4 & $\begin{array}{l}2.4 \\
(0.91-6.3)\end{array}$ & 0.07 & 4 & 3 & 1 & $\begin{array}{l}2.1 \\
(0.30-15)\end{array}$ & 0.4 \\
\hline 2006 & 13,725 & 20 & 16 & 4 & $\begin{array}{l}2.7 \\
(1.01-7)\end{array}$ & 0.04 & 8 & 7 & 1 & $\begin{array}{l}4.2 \\
(0.61-28.8)\end{array}$ & 0.1 \\
\hline 2007 & 13,687 & 22 & 19 & 3 & $\begin{array}{l}3.9 \\
(1.27-11.7)\end{array}$ & 0.02 & 9 & 9 & 0 & - & - \\
\hline 2008 & 13,849 & 14 & 14 & 0 & - & - & 4 & 4 & 0 & - & - \\
\hline 2009 & 17,110 & 19 & 16 & 3 & $\begin{array}{l}3.35 \\
(1.1-1.2)\end{array}$ & 0.03 & 17 & 16 & 1 & $\begin{array}{l}8.7 \\
(1.25-60)\end{array}$ & 0.02 \\
\hline 2010 & 22,607 & 31 & 28 & 3 & $\begin{array}{l}5.4 \\
(1.8-16.4)\end{array}$ & 0.003 & 24 & 23 & 1 & $\begin{array}{l}12.2 \\
(1.75-85)\end{array}$ & 0.01 \\
\hline 2011 & 25,557 & 30 & 28 & 2 & $\begin{array}{l}7.7 \\
(1.97-30)\end{array}$ & 0.003 & 14 & 14 & 0 & - & - \\
\hline 2012 & 23,902 & 20 & 20 & 0 & - & - & 10 & 10 & 0 & - & - \\
\hline 2013 & 23,750 & 18 & 16 & 2 & $\begin{array}{l}4.7 \\
(1.2-18.4)\end{array}$ & 0.02 & 10 & 10 & 0 & - & - \\
\hline 2014 & 17,981 & 6 & 5 & 1 & $\begin{array}{l}3.2 \\
(0.5-21.9)\end{array}$ & 0.2 & 9 & 9 & 0 & - & - \\
\hline
\end{tabular}

can more easily provide preventive and vaccination programs for their people than countries with lower income [11,12]. Education is another important factor that can significantly decrease the rate of TTls among blood donors, mostly by reducing risky behaviors [13].

Due to the crucial role of blood safety in blood transfusion services, huge efforts are made to improve the safety of blood and its components $[1,2,6,10,14]$. These efforts are performed in different stages of blood transfusion processes, from blood donor selection to blood release $[3,10,15]$. Donor selection is an important step in blood safety and different studies have revealed that suitable and appropriate donor selection can significantly improve blood safety $[15,16]$. It was shown that blood components of repeated and regular blood donors have a lower risk of $\mathrm{TI}$ transmission than those of first-time donors $[10,17,18,19,20]$. On the other hand, it has been shown that first-time donors are the most common donors in blood transfusion centers $[10,18]$. These two issues highlight the importance of the donor selection process in blood transfusion centers, which can significantly improve the safety of blood and blood components. In our study, about one-third of the donors were first-time donors. Similar results were observed in several other studies in Iran and other countries $[15,17,18]$.
In our study, similar to many others, it was revealed that TIs are more common among first-time donors than repeated and regular donors $[6,15]$. The CUE system is a commonly used system in most blood transfusion centers. However, its usefulness is questionable based on a considerable number of studies $[21,22,23]$. Despite this issue, the IBTO has used this system to improve the safety of blood and its components $[15,24]$. Several studies confirmed that CUE is a relatively costbeneficial system that can significantly improve the safety of blood products $[15,25]$. In our study, this issue was observed and the CUE option was more commonly used by first-time donors. In our study, about $2 \%$ of the first-time donors used the CUE option (CUE-positive), while only $0.8 \%$ of repeated and regular donors did. This rate of CUE positivity among the first-time donors in our study is lower than that in the study of Vogler et al. [26], who reported about 5\% CUE positivity among their first-time donors.

Moreover, a significantly higher prevalence of $\Pi$ Is was observed among first-time donors with positive CUE in comparison with the CUE-negative first-time donors. The higher prevalence of Thls among the first-time donors and the CUE-positive firsttime donors is in agreement with other studies conducted in Iran, Australia, the United Kingdom, and the Netherlands $[4,15,17,24,25]$. 
In our study, the prevalence of $\mathrm{HBsAg}$ and HCV was $0.13 \%$ and $0.07 \%$ among blood donors, respectively, and $0.44 \%$ and $0.2 \%$ in the first-time blood donors, respectively. This rate of infection in the KBTC is lower than those of other studies $[1,2,5,27,28,29]$. This discrepancy in the prevalence of $T$ Is in different populations around the world reflects a variety of high-risk behaviors, population risks, health statuses, and selection procedures in those regions.

In our study, the prevalence of HBsAg and HCV infection had increased during 2005-2007 and 2009-2011 among voluntary first-time donors, while Farshadpour et al. [4], Amini Kafi-Abad et al. [30], and Khodabandehloo et al. [31] reported a decreased trend in the prevalence of HBV and HCV between 2004 and 2012. The reason for this increase in our study could be related to the significant increase in the number of first-time blood donors, which increased from 4,139 in 2005 to 7,031 in 2011. Also, this increase could be related to a combination of other factors including vaccination against $\mathrm{HBV}$; low public knowledge about blood-borne infections and routes of transmission in the past such as traditional tattoos, traditional circumcision, and cupping therapy; and the effectiveness of prospective donor screening measures.

It seems that a higher rate of TIs among first-time donors is a relatively significant challenge for blood transfusion centers and special policies such as CUE should be considered for these donors to improve the safety of blood and its components.

Similar to other studies, our results showed a higher prevalence of $\mathrm{HBsAg}$ compared to HCV in both total and firsttime donors [30,32]. This high prevalence may be due to the higher rate of HBV in the general population of this province, whereas this issue was not determined in any other study and consequently further studies are required to confirm this issue $[33,34]$.

\section{Conclusion}

Due to the high rate of TIs among first-time donors, it is crucial to implement some preventive programs among this common type of blood donors to reduce the overall incidence of TIs among blood recipients.

\section{Acknowledgment}

The authors would like to thank all staff members of the KBTC.

\section{Ethics}

Ethics Committee Approval: This study was approved by the ethics committee of Yasuj University of Medical Sciences (IR. Yuma.rec.1396.22).

Informed Consent: Informed consent is not applicable to this study.

\section{Authorship Contributions}

Analysis or Interpretation: H.R.N., A.D., F.R.; Literature Search: H.R.N., A.D., F.R.; Writing: H.R.N., A.D., F.R.

Conflict of Interest: The authors declare no conflict of interest.

Financial Disclosure: The authors declare that this study received no financial support.

\section{References}

1. Pallavi $P$, Ganesh $C$, Jayashree $K$, Manjunath $G$. Seroprevalence and trends in transfusion transmitted infections among blood donors in a university hospital blood bank: a 5 year study. Indian J Hematol Blood Transfus $2011 ; 27: 1-6$

2. Gurol E, Saban C, Oral O, Cigdem A, Armagan A. Trends in hepatitis B and hepatitis $C$ virus among blood donors over 16 years in Turkey. Eur J Epidemiol 2006;21:299-305.

3. Surgenor DM, Wallace EL, Hao SH, Chapman RH. Collection and transfusion of blood in the United States, 1982-1988. N Engl J Med 1990;322:1646-1651.

4. Farshadpour F, Taherkhani R, Tajbakhsh S, Gholizadeh Tangestani M, Hajiani G, Sharifi N, Taherkhani S, Nejadbolkheyr A. Prevalence and trends of transfusion-Transmissible viral infections among blood donors in south of Iran: an eleven-year retrospective study. PLoS One 2016;11:e0157615.

5. Motayo BO, Faneye AO, Udo UA, Olusola BA, Ezeani I, Ogiogwa Jl. Seroprevalence of transfusion transmissible infections (TI), in first time blood donors in Abeokuta, Nigeria. Afr Health Sci 2015;15:19-24.

6. Dhar G, Sarkar A, Sen S, Ghosh S, Mukhopadhyay B, Ghosh T. Patterns of infective sero positivity among blood donors in a rural medical college regional blood transfusion centre: a retrospective study. Nepal J Med Sci 2013;2:3-8.

7. Korelitz JJ, Williams AE, Busch MP, Zuck TF, Ownby HE, Matijas L, Wright DJ. Demographic characteristics and prevalence of serologic markers among donors who use the confidential unit exclusion process: the Retrovirus Epidemiology Donor Study. Transfusion 1994;34:870-876.

8. Asif N, Hassan K. Voluntary blood donation. Journal of Islamabad Medical \& Dental College 2015;5:1-2.

9. Garg S, Mathur D, Garg D. Comparison of seropositivity of HIV, HBV, HCV and syphilis in replacement and voluntary blood donors in western India. Indian J Pathol Microbiol 2001;44:409-412.

10. Maghsudlu $M$, Nasizadeh S. Iranian blood donors' motivations and their influencing factors. Transfus Med 2011;21:247-252.

11. Shiferaw E, Tadilo W, Melkie I, Shiferaw M. Sero-prevalence and trends of transfusion-transmissible infections among blood donors at Bahir Dar district blood bank, northwest Ethiopia: a four year retrospective study. PLoS One 2019;14:e0214755.

12. World Health Organization. Global Status Report on Blood Safety and Availability. Geneva, World Health Organization, 2017.

13. Gonçalez $\Pi$, Sabino EC, Salles NA, de Almeida-Neto $C$, Mendrone A Jr, Dorlhiac-Laccer PE, Liu J, Murphy EL, Schreiber GB; REDS-II International Brazil Study. The impact of simple donor education on donor behavioral deferral and infectious disease rates in Sao Paulo, Brazil. Transfusion 2010;50:909-917.

14. Glynn SA, Kleinman SH, Schreiber GB, Busch MP, Wright DJ, Smith JW, Nass $\mathrm{CC}$, Williams AE. Trends in incidence and prevalence of major transfusiontransmissible viral infections in US blood donors, 1991 to 1996. JAMA 2000;284:229-235.

15. Kasraian L, Tavasoli A. Positivity of HIV, hepatitis B and hepatitis C in patients enrolled in a confidential self-exclusion system of blood donation: a cross-sectional analytical study. Sao Paulo Med J 2010;128:320-323. 
16. Kaur $H$, Mannan R, Manjari M. Seroprevalence of the blood borne infections in blood donors: our 11 year (2001-2011) experience in a tertiary care teaching hospital at Amritsar (Punjab). Int J Adv Res 2014;2:967-971.

17. Maia CN, Ruas MdO, Urias EVR. Confidential unit exclusion at the regional blood bank in Montes Claros: Fundação Hemominas. Rev Bras Hematol Hemoter 2012;34:17-20.

18. Shahshahani HJ, Vaziri M, Mansouri F. Seven years trends in prevalence of transfusion-transmissible viral infections in Yazd blood transfusion organization. Iran J Ped Hematol Oncol 2013;3:119.

19. Barreto CC, Sabino EC, Gonçalez TI, Laycock ME, Pappalardo BL, Salles NA, Wright DJ, Chamone DF, Busch MP. Prevalence, incidence, and residual risk of human immunodeficiency virus among community and replacement first-time blood donors in São Paulo, Brazil. Transfusion 2005;45:17091714.

20. Mbanya $D$, Takam $D$, Ndumbe $P$. Serological findings amongst first-time blood donors in Yaounde, Cameroon: is safe donation a reality or a myth? Transfus Med 2003;13:267-273.

21. Zou S, Notari I, Musavi F, Dodd R. Current impact of the confidential unit exclusion option. Transfusion 2004;44:651-657.

22. O'Brien S, Fan W, Xi G, Yi QL, Goldman M. Evaluation of the confidential unit exclusion form: the Canadian Blood Services experience. Vox Sang 2010;98:138-144.

23. de Almeida-Neto $C$, Liu J, Wright DJ, Mendrone-Junior $A$, Takecian $P L$, Sun Y, Ferreira JE, de Alencar Fischer Chamone D, Busch MP, Sabino EC; NHLBI Retrovirus Epidemiology Donor Study-II (REDS-II), International Component. Demographic characteristics and prevalence of serologic markers among blood donors who use confidential unit exclusion (CUE) in São Paulo, Brazil: implications for modification of CUE polices in Brazil. Transfusion 2011;51:191-197.

24. Omidkhoda A, Gharehbaghian A, Jamali M, Ahmadbeigi N, Hashemi SM, Rahimi A, Soleimani M. Comparison of the prevalence of major transfusiontransmitted infections among Iranian blood donors using confidential unit exclusion in an Iranian population: transfusion-transmitted infections among Iranian blood donors. Hepat Mon 2011;11:11.
25. Vandewalle G, Baeten M, Bogaerts $K$, Vandekerckhove P, Compernolle V. Evaluation of 6 years of confidential unit exclusion at the Belgian Red Cross Flanders Blood Service. Vox Sang 2014;106:354-360.

26. Vogler IH, Saito M, Spinosa AA, Silva MCd, Munhoz E, Reiche EMV. Effectiveness of confidential unit exclusion in screening blood donors of the regional blood bank in Londrina, Paraná State. Rev Bras Hematol Hemoter 2011;33:347-352.

27. Bhawani Y, Rao PR, Sudhakar V. Seroprevalence of transfusion transmissible infections among blood donors in a tertiary care hospital of Andhra Pradesh. Biol Med 2010;2:45-48.

28. Hussein NR, Haj SM, Almizori LA, Taha AA. The prevalence of hepatitis B and $C$ viruses among blood donors attending blood bank in Duhok, Kurdistan Region, Iraq. International Journal of Infection 2017;4:e39008.

29. Farzadegan H, Harbour C, Ala F. The prevalence of hepatitis B surface antigen and its antibody in blood donors and high risk groups in Iran. Vox Sang 1979;37:182-186.

30. Amini Kafi-Abad S, Rezvan H, Abolghasemi H, Talebian A. Prevalence and trends of human immunodeficiency virus, hepatitis B virus, and hepatitis C virus among blood donors in Iran, 2004 through 2007. Transfusion 2009;49:2214-2220.

31. Khodabandehloo M, Roshani D, Sayehmiri K. Prevalence and trend of hepatitis $C$ virus infection among blood donors in Iran: a systematic review and meta-analysis. J Res Med Sci 2013;18:674-682.

32. Mohammadali F, Pourfathollah AA. Changes in frequency of HBV, HCV, HIV and syphilis infections among blood donors in Tehran province 2005-2011. Arch Iran Med 2014;17:613-620.

33. Sajjadi SM, Pourfathollah AA, Mohammadi $S$, Nouri B, Hassanzadeh R, Rad F. The prevalence and trends of hepatitis $B$, hepatitis $C$, and HIV among voluntary blood donors in kohgiluyeh and boyer-ahmad transfusion center, Southwestern Iran. Iranian journal of public health. 2018;47:944.

34. Rad F, Sajjadi SM, Azizi A, Maghsudlu M. Confidential unit exclusion (CUE): Double edged sword for blood transfusion center: A ten-year study on volunteer blood donors in Kohgiluyeh and Boyer Ahmad province, Iran. Transfusion Clinique et Biologique 2019;26:253-256. 